Review Article

\title{
OBESITY, DIABETES AND LEPTIN: LESSONS LEARNED FROM OBESE HYPERGLYCEMIC MICE
}

\author{
Meftun Ahmed \\ Department of Physiology, Ibrahim Medical College, Dhaka, Bangladesh. The Oxford Centre for Diabetes, \\ Endocrinology and Metabolism (OCDEM), University of Oxford, Oxford, UK
}

\begin{abstract}
The recent epidemic nature of obesity and association of obesity with the development of type 2 diabetes demands dissection of the pathophysiology of this morbid disorder which is essential for better understanding of the process of evolution of insulin resistance. Different animal models have been used to explore the mechanism linking obesity to insulin resistance and type 2 diabetes. The discovery of $o b$ gene and its product, leptin, has revealed the signaling system regulating energy balance in rodents. The mice lacking this $o b$ gene, $o b / o b$ mice, display obesity, hyperglycemia and hyperinsulinemia and has been extensively used for the study of type 2 diabetes and for potential drug development. In this review, the features and development of obese hyperglycemic syndrome, the role of leptin in the pathogenesis of the syndrome and finally the applicability of the findings in rodents to body weight regulation and pathogenesis of insulin resistance in humans have been summarized.
\end{abstract}

Ibrahim Med. Coll. J. 2008; 2(2): 72-84

\section{Introduction}

In mice a recessive mutant gene, $o b$, produces obesity leading to hyperinsulinemia and hyperglycemia. Such spontaneous development of obesity and hyperglycemia in mice is generally referred as obese-hyperglycemic syndrome. ${ }^{1}$ They were first discovered at the Jackson Laboratory, USA in 1949 and found to be homozygous for an autosomal recessive mutation on chromosome $6{ }^{2,3}$ The mutation was propagated in C57BL/6J inbred strain, and also C57BL/KsJ. ${ }^{4,5}$ Breeding pairs from Jackson Laboratory were obtained by University of Uppsala, Sweden and later by University of Umeå, Sweden (Umeå $o b){ }^{4,6}$ These colonies in Sweden are non-inbred colony and the massive islets of Langerhans of the obese mice have been used in studies involving insulin release and islet metabolism. ${ }^{7-9}$ Continuous research with this $o b / o b$ mice led to the discovery of the $o b$ gene product and indeed opened a new horizon for the diabetes and obesity research. This $o b$ gene product markedly attenuated body weight by reducing food intake and body fat when injected into $o b / o b$ or normal mice ${ }^{10,11}$ and therefore, was named leptin from the Greek word leptos, meaning thin. The recent official nomenclature for the $o b$ gene in mice is Lep and the $o b / o b$ mice in C57BL/6J background strain is B6.V$L e p^{o b}$. In this review the features and development of obese hyperglycemic syndrome and the role of leptin in the pathogenesis of the syndrome as well as the applicability of the findings in rodents to body weight regulation and pathogenesis of insulin resistance in humans has been discussed briefly.

\section{Features of obese hyperglycemic syndrome}

Marked obesity, hypoactivity, hyperphagia, transient hyperglycemia (subsiding around 14-16 weeks), severe hyperinsulinemia and insulin resistance are the cardinal features of obese hyperglycemic syndrome when $o b$ gene is expressed in the $\mathrm{C} 57 \mathrm{BL} / 6 \mathrm{~J}$ strain background..$^{5,12-14}$ In contrast to the $\mathrm{C} 57 \mathrm{BL} / 6 \mathrm{~J}$ strain, $\mathrm{BL} / \mathrm{Ks} o b / o b$ mice are characterized by obesity, severe hyperglycemia and glucose intolerance, transient hyperinsulinemia, islet atrophy and early death. ${ }^{14,15}$

Address for Correspondence:

Dr Meftun Ahmed, Associate Professor, Department of Physiology, Ibrahim Medical College, 122 Kazi Nazrul Islam Avenue, Shahbag, Dhaka, Bangladesh, Tel:8801715425535, Email:meftun.khandker@drl.ox.ac.uk; meftun@hotmail.com 
Early signs of the obese hyperglycemic syndrome are lower oxygen consumption, ${ }^{16}$ decreased thermogenesis ${ }^{17}$ and increased weight gain. ${ }^{12}$

\section{Metabolism}

Hyperglycemia and glucosuria are prominent features of the obese mice. Hyperglycemia is related to increased gluconeogenesis and glycogenolysis, to altered pancreatic function and also to a diminished peripheral glucose uptake..$^{4,18,19}$ Gluconeogenesis is enhanced in obese mice despite the hyperinsulinemic state; probably as a result of adrenal glucocorticoid stimulation. ${ }^{4,18,20}$ The activity of enzymes of both the glycolytic and gluconeogenic hepatic pathways is increased..$^{21}$ The turnover of glycogen is also increased in $o b / o b$ mice as a result of high activity of glycogen synthase and phosphorylase. This change might be secondary to increased glucagon secretion. ${ }^{18}$ Hyperglycemia causes glucosuria resulting in polydipsia and polyuria, which is recognized through moistening of the bedding. ${ }^{6}$

The obese mice are hypercholesterolemic. ${ }^{12,22}$ However, the increase is primarily in high-density lipoprotein cholesterol, so that atherosclerotic lesions are unusual in this mouse model. ${ }^{23}$ Plasma triglyceride levels are also elevated in the $o b / o b$ mice. Rate of lipogenesis in the liver and adipose tissue is more than doubled and both intraperitoneal and subcutaneous deposit of fat is increased. ${ }^{4,18}$ The increased amount of lipids stored by $o b / o b$ mice is accommodated through both hyperplasia and hypertophy of adipocytes; whereas in other genetic obesities in mice, increase in fat depots is entirely due to cell hypertrophy. ${ }^{24}$

\section{Body weight}

The Swedish and Jackson colony $o b / o b$ mice gain weight rapidly during the first three months of life and reach a maximum body weight of 60-70 grams at an age of 56 months. Then the body weight of $o b / o b$ mice remains stable until they are 10-15 months old (Fig 1). Later there is a slight reduction in body weight, and a rapid decrease may be seen shortly before spontaneous death occurs. ${ }^{12,25-27}$ In contrast, lean littermates reach their maximal weight of 30-40 grams in 3-4 months and then body weight remains stable till death. However, different pattern of weight gain has also been observed in different breeding stocks of $o b / o b$ mice $^{2,28}$ and the variability may be related to the diet. ${ }^{12}$ The increased weight of obese mice due to high fat content and the accumulation of adipose tissue mass results from hyperphagia. ${ }^{4,16}$

\section{Life span}

The average lifespan of obese hyperglycemic mice in Jackson colony is about 450 days, which is approximately 300 days shorter than that of lean mice. ${ }^{28,29}$ Compared with their lean littermates, the Uppsala obese mice usually have a lifespan a few months shorter, most of them dying between 20 and 24 months of age. ${ }^{12}$ The incongruity of life span of $o b / o b$ mice among different colonies possibly related to the $\operatorname{diet.~}^{12,28}$

\section{Islet morphology and biochemistry}

Pancreatic islets of obese hyperglycemic mice $(o b / o b)$ are the most extensively studied among the several strains of genetically obese mice islets. In the $o b / o b$ strain, there is an increase in islet cell mass due to marked islet cell hyperplasia and hypertrophy. ${ }^{30-32}$ Both $\alpha$ - and $\beta$-cells are increased in number and size,
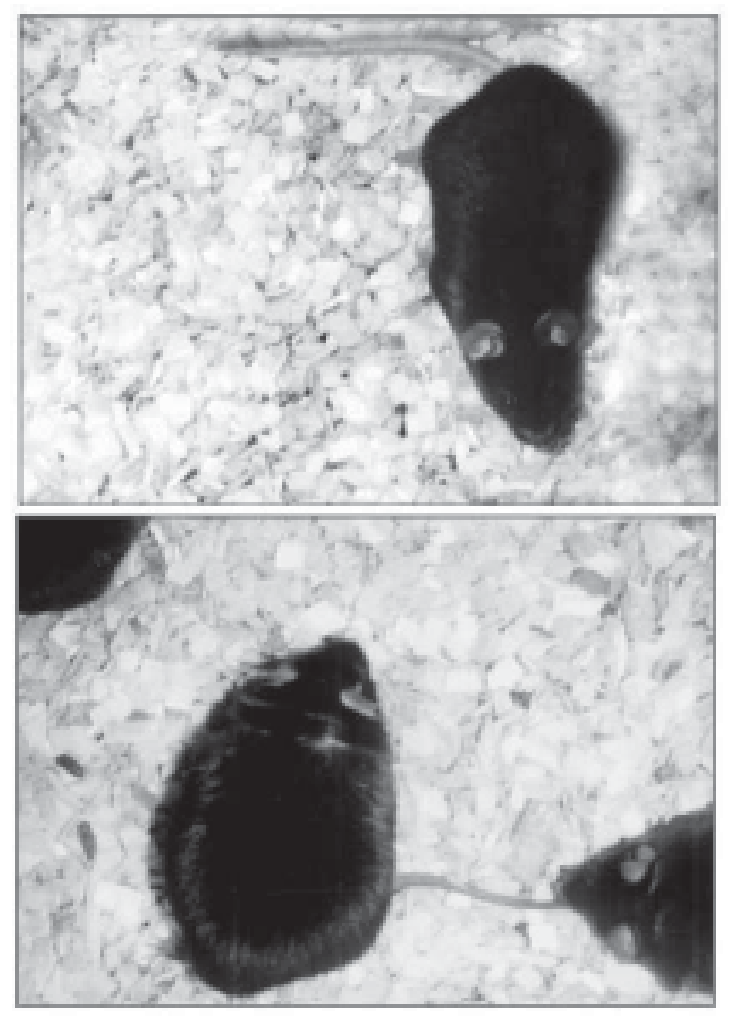

Fig-1. Lean C57BL/6J (top) and an obese mice (B6.VLep $^{o b}$, bottom). 
however more than $90 \%$ of the cells in the islets are $\beta$-cells. ${ }^{7,33}$ The size of the islets is related to body weight and will decrease following caloric deprivation. ${ }^{1,34}$ Adult obese mice have larger and more numerous islets compared with lean mice of similar age. ${ }^{27,31}$ On average, their islets are $60 \%$ larger in diameter than islets of lean littermates. ${ }^{35}$ The greatly increased total islet volume in the $o b / o b$ mice is mainly dependent on an increased number of islets in the larger size classes. ${ }^{31}$

Immunocytochemical studies demonstrate that glucagon, gastric inhibitory polypeptide and somatostatin containing cells were intermingled with the $\beta$-cells in obese mouse islets in addition to their peripheral localization. ${ }^{32,36}$ In contrast, its lean littermates show only a peripheral localization of these cell types. There are signs of $\beta$-cell degranulations in islets from obese mice with increased nuclear and nucleolar size. ${ }^{1,37-39}$ The islets of the obese mice are remarkably hyperemic ${ }^{30,39,40}$ pseudocysts, dilated ducts and dilated capillaries are also common findings in $o b$-mouse islets. ${ }^{32}$

The obese hyperglycemic syndrome is characterized by an increase in the extractable insulin of pancreas in both young ( 2 months old) and mature (4 months old) $o b / o b$ mice than their lean littermates. ${ }^{37,41}$ Whereas the pancreatic content of glucagon and pancreatic polypeptide are higher in $o b / o b$ mice $^{42-45}$ the somatostatin content of, and release from, pancreatic islets is approximately 6 times lower than that in islets of the lean mice. ${ }^{46}$

\section{Beta-cell defects}

The $o b / o b$ mice exhibit an increased sensitivity to low levels of glucose and a left shift in the glucose-response curve. ${ }^{35}$ The threshold for glucose-induced insulin secretion from perifused islets in fed $o b / o b$ mice is about $2 \mathrm{mmol} / \mathrm{L}$ and in $24 \mathrm{hrs}$ fasted obese mice is about $3 \mathrm{mmol} / \mathrm{L} .{ }^{47}$ In contrast, islets from lean mice exhibit considerably higher thresholds - about 5 and 7 $\mathrm{mmol} / \mathrm{L}$ glucose in fed and $24 \mathrm{hrs}$ starved lean mice, respectively. When insulin secretion was measured from equally-sized islets in $o b / o b$ (Uppsala colony) and lean mice, no significant differences were noted between them both in basal and higher glucose level. ${ }^{48}$ However, in a similar experimental protocol, islets of $o b / o b$ mice from Michigan colony hypersecreted insulin in response to high concentrations of glucose than that of lean mice. ${ }^{47}$ Neurotransmitters and hormones that normally potentiate insulin secretion only above $6 \mathrm{mM}$ glucose in lean mice are found to stimulate insulin secretion in $o b / o b$ mice at basal glucose levels. ${ }^{35,47}$

Islets from obese mice are characterized by elevated glycogen level, increased phosphorylase activity and an increased amount of glycogen synthase indicating an increased turnover of glycogen. ${ }^{49}$ Glucose-6phosphatase activity is also increased in $o b / o b$ mice islets and a significant amount of glucose is metabolized by glucose cycling (GC). Only 3-5\% of the glucose phosphorylated is dephosphorylated by the lean mice islets irrespective of the glucose concentration. ${ }^{50,51}$ In contrast, in the $o b / o b$ mice islets $\mathrm{GC}$ is $18 \%$ at $5.5 \mathrm{mM}$ and $30 \%$ at $16.7 \mathrm{mM}$ glucose. ${ }^{50}$

The $o b / o b$ islets of Norwich colony are permanently more depolarized even in the absence of a primary stimulus to secretion than the lean ones. ${ }^{52}$ While $\beta$ cells of lean mice show continuous spike activity above $16 \mathrm{mM}$ glucose, ob/ob $\beta$-cells often exhibit a burst pattern of electrical activity at glucose concentrations as high as $33 \mathrm{mM} .{ }^{52,53}$ They also exhibit an increased responsiveness to quinine ( $\mathrm{K}_{\mathrm{ATP}}$ channel blocker) and apamin (a $\mathrm{Ca}^{2+}$-dependent $\mathrm{K}^{+}$channel blocker) suggesting an altered sensitivity of $\mathrm{K}_{\text {ATP }}$ and $\mathrm{Ca}^{2+}$ activated $\mathrm{K}^{+}$channels. ${ }^{54}$ Electrophysiological studies and ${ }^{86} \mathrm{Rb}^{+}$efflux data also suggest a modified $\mathrm{K}^{+}$ permeability in pancreatic $\beta$-cells from Norwich $o b /$ ob mice. ${ }^{52,53}$ However, with patch-clamp measurements, $\mathrm{K}_{\mathrm{ATP}}$ channels in $o b / o b$ mice islets display a normal behavior in respect of conductance, ionic selectivity, kinetic behavior, voltage dependency, and sensitivity to glucose and ATP/ADP. ${ }^{55}$

Islets of $o b / o b$ mice respond to $\mathrm{Ca}^{2+}$ channel blockers, verapamil and nifedipine, with a decreased sensitivity. ${ }^{56} \mathrm{X}$-ray microanalysis demonstrate a significant lower value of total calcium concentration in $o b / o b$ islets than their lean counterparts indicating an alteration in calcium binding molecules in $\mathrm{ob} / \mathrm{ob}$ islets. ${ }^{57}$ Their insulin secretory capacity is also less dependent on extracellular $\mathrm{Ca}^{2+}$ than in islets of lean mice. ${ }^{58}$ But studies with fura- 2 do not reveal any changes in glucose-mediated $\mathrm{Ca}^{2+}$ fluxes; ${ }^{59}$ and effects of glucose and other nutrient secretagogues on intracellular $\mathrm{Ca}^{2+}\left(\left[\mathrm{Ca}^{2+}\right]_{\mathrm{i}}\right)$ changes in single $\beta$-cells appear similar both in $o b / o b$ and lean mice (unpublished data). However, in cultured $o b / o b$ islets cAMP induces fast oscillations in $\left[\mathrm{Ca}^{2+}\right]_{\mathrm{i}}$ in the presence of glucose, 
Obesity, diabetes and leptin

suggesting hypersensitivity of $\mathrm{Ca}^{2+}$ channels to cAMPmediated events. ${ }^{60}$ The islets of $o b / o b$ mice accumulate less cAMP than those of lean mice in response to forskolin but their insulin secretion is enhanced too much higher values. ${ }^{58} \mathrm{Newman}^{49}$ found no significant difference in cAMP levels between islets of lean and obese mice but methylxanthine and glucagon induced a more rapid turnover of cAMP and eventually increased cAMP levels more markedly in $o b / o b$ islets. Atkins and Matty ${ }^{61}$ have shown that both adenylate cyclase and phosphodiesterase activity are higher in the obese mice islets than the lean mice. However, Black et $\mathrm{al}^{58,62}$ have provided conflicting results. They have demonstrated that islets of the $o b / o b$ mice accumulate less cAMP than that of the lean mice in response to a given dose of forskolin or pertusis toxin. ${ }^{58,62}$ The discrepancy in results may depend on the colonies of $o b / o b$ mice used and also to the feeding state. For example, in fasting but not in fed state, the $o b / o b$ islet cAMP levels are significantly higher than in the lean mice. ${ }^{63}$ Studies with acetylcholine, cholecysytokinin and phorbol esters, eg, TPA (tetradecanoyl phorbol acetate) and PMA (phorbol 12myristate 13 acetate) demonstrate that insulin secretion in response to PLC-PKC activation is also markedly enhanced in islets from $o b / o b$ mice when compared to their lean littermates. ${ }^{64-66}$ Activation of phospholipase $\mathrm{C}$ signaling pathway also generates ample $\left[\mathrm{Ca}^{2+}\right]_{\mathrm{i}}$ transients in glucose-stimulated $\beta$-cells from $o b / o b$ mice than lean mice. ${ }^{60}$

Monoamines (dopamine and 5HT) are stored in the insulin secretory granules of $\beta$-cells and may affect the granule maturation and (or) exocytotic procedure. ${ }^{67}$ Glucose itself induces a significant suppression of islet monoamine oxidase (MAO) activity within 2 min after an intravenous injection. ${ }^{68}$ Generally, MAO levels rise as glucose levels fall, but this correlation is not observed in islets of $o b / o b$ mice. ${ }^{69}$

\section{Adrenals}

Obese hyperglycemic mice have an adrenal hypertrophy and it's related to the cortical part with increased synthesis of corticosterone, while no significant differences were noted for the medulla. ${ }^{1,13,70}$

\section{Kidneys}

Diffuse nodular lipohyaline deposits are present in the kidney in aging obese mice and they are primarily localized to the mesangial cells. ${ }^{71,72}$

\section{Reproductive organs}

Obese mice are sterile. ${ }^{2}$ Infertility is an absolute characteristic of the $o b / o b$ females; however about $20 \%$ of the $o b / o b$ male can reproduce. ${ }^{73}$ The level of $\mathrm{LH}, \mathrm{FSH}$ and testosterone in serum is lower in obese mice compared to their lean littermates. ${ }^{18}$ In female obese mice the ovaries and uterus remain atrophic ${ }^{74}$ whereas the male counterpart is characterized by smaller testes, hypoplastic seminal vesicles, atrophic interstitial Leydig cells and a slight decrease in the number of spermatozoa. ${ }^{73}$ Thus, it has been suggested that there is a persistent immaturity of the hypothalamic-pituitary axis in obese mice. ${ }^{75}$

\section{Endocrine abnormalities}

Serum insulin could be elevated up to 50 fold in 6 months $o b / o b$ mice $^{18}$ as a result of increased synthesis and secretion of insulin from the pancreatic $\beta$ cells. ${ }^{12,26,27}$ Pancreatic glucagon content is higher in $o b / o b$ mice than their lean littermates and they exhibit inappropriate hyperglucagonemia. ${ }^{45,63,78-81}$ In $o b / o b$ mice, there is increased pituitary content and secretion of ACTH. ${ }^{18,26}$ On the other hand, there is a diminished urinary excretion of epinephrine in obese homozygous mice suggesting a decreased adrenal medullary activity. ${ }^{82}$ Hypothalamic concentration of LHRH or

Table-1: Summary of â-Cell Defects in ob/ob Mice

\begin{tabular}{|c|c|c|}
\hline Features & Changes & References \\
\hline $\begin{array}{l}\text { Glycogen Turnover \& } \\
\text { Glucose Cycling }\end{array}$ & $\uparrow$ & 49,50 \\
\hline GSIS & $\uparrow$ & 76 \\
\hline Threshold for GSIS & $\downarrow$ & 47 \\
\hline $\mathrm{K}_{\text {ATP }}$ Channel Activity & Altered/No Change & $54 / 55$ \\
\hline Total Calcium & $\downarrow$ & 57 \\
\hline $\mathrm{Ca}^{2+}$ Handling & Altered/Normal & $\begin{array}{l}56,77 / \\
\text { Uppsala group }\end{array}$ \\
\hline $\begin{array}{l}\mathrm{Ca}^{2+} \text {-activaed } \\
\mathrm{K}^{+} \text {Channel }\end{array}$ & Altered & 52,54 \\
\hline Vesicle MAO & $\downarrow$ & 69 \\
\hline $\begin{array}{l}\text { Adenylate Cyclase } \\
\text { Activity }\end{array}$ & Higher/Impaired & $61 / 62$ \\
\hline Islet cAMP Level & Higher/No Change & $63 / 49$ \\
\hline Sensitivity to cAMP & $\uparrow$ & $49,60,62,77$ \\
\hline PLC-PKC Sensitivity & $\uparrow$ & $60,64-66$ \\
\hline
\end{tabular}

GSIS=Glucose-stimulated insulin secretion; $\mathrm{MAO}=$ Monoamine oxidase; PLC-PKC=Phospholipase C-protein kinase C 
GnRH as well as serum FSH-LH, testosterone and female sex hormones in $o b / o b$ mice are reduced. ${ }^{75,83}$

Many symptoms in adult $o b / o b$ mice, eg, their low metabolic rate, hypercholesterolemia, decreased body temperature, susceptibility to cold and hypoactivity suggest functional hypothyroidism. ${ }^{18,84}$ But conflicting results in serum concentrations of thyroid hormones (serum TSH, T3 and T4 and also hypothalamic content of TRH) in $o b / o b$ mice have been reported - either lower, ${ }^{85}$ higher ${ }^{86,87}$ or the same ${ }^{88-90}$ as in lean mice. However, van der Kroon et $\mathrm{al}^{84}$ have tried to explain the discrepancy in results about thyroid activity in $o b /$ $o b$ mice and provided support for the hypothesis that the obese hyperglycemic syndrome in mice is characterized by congenital hypothyroidism. Mobley and Dubuc ${ }^{91}$ found that obese mice have significantly reduced hormone concentrations between 10 and 21 days of age. Thereafter, the values remained equal to, or above those of their lean littermates. This result is consistent with human data provided by Ozata et al. ${ }^{92}$ They have demonstrated that thyroid function is abnormal only in the obese child of the leptin gene mutant family but is normal in the adult patients. Thus, it is most likely that in adult $o b / o b$ mice pituitarythyroid hormone levels remain normal and their apparent hypothyroidism is largely independent of hormone availability to target tissues rather depends on defective target tissue responses. ${ }^{86,93}$ This interpretation is supported by a number of observations, including decreased $5^{\prime}$-deiodinase activity in brown adipose tissue, ${ }^{94}$ liver ${ }^{90}$ and kidney; ${ }^{89}$ and decreased transport of $\mathrm{T} 3$ across the hepatic plasma membrane and a reduced nuclear $\mathrm{T} 3$ receptor occupancy. ${ }^{95,96}$ These findings suggest that T3 availability to target tissues may be impaired in obese mice, which may contribute to diminished thyroid hormone expression and heat production in these animals. ${ }^{89}$ Furthermore, the thyroid-stimulated component of $\mathrm{Na}^{+}-\mathrm{K}^{+}-\mathrm{ATPase}$ is deficient in $\mathrm{ob} / \mathrm{ob}$ mice. ${ }^{18}$ The activity of $\mathrm{Na}^{+}-\mathrm{K}^{+}$-ATPase is low in liver, kidney and skeletal muscle of $o b / o b$ mice. ${ }^{97}$ And a defective regulation of this enzyme may lead to decreased thyroid action. ${ }^{18}$

\section{Others}

There are some abnormalities in the brown adipose tissue in obese hyperglycemic mice, such as decreased sympathetic activity and decreased mitochondrial proton conductance; ${ }^{98,99}$ increased rates of $\mathrm{Ca}^{2+}$ uptake and release. ${ }^{100}$ Decreased $\mathrm{Na}^{+}-\mathrm{K}^{+}$-ATPase activity in muscle and liver tissue of the $o b / o b$ mice has also been demonstrated. ${ }^{101}$ They have a defect in wound collagen accumulation and thus exhibit impaired wound healing. ${ }^{102,103}$

\section{Development of early $o b / o b$ syndrome}

Time course of the developing obese hyperglycemic syndrome indicates that the obesity, hyperinsulinemia, and skeletal growth deficits that characterize mature $o b / o b$ mice develop before weaning and are clearly defined as early as 17 days of age. ${ }^{13}$ Other studies regarding developmental sequence of the abnormalities demonstrate that obesity precedes hyperinsulinemia, which precedes the onset of insulin resistance and hyperglycemia. ${ }^{13,104,105}$ When lean and obese mice are compared as groups there is a significant difference in weight at day 6 in Jackson colony ${ }^{16}$ or at day 12 in Swedish colony. ${ }^{106}$ And at day 18, clinical diagnosis of the $o b / o b$ syndrome could be made with $100 \%$ certainty. Already at day 17, Dubuc ${ }^{13}$ and Garthwaite et $\mathrm{al}^{26}$ found higher insulin levels in obese mice, others reported about day 20. ${ }^{12,106}$ However, there is no significant rise in blood sugar until day 22, but afterward, obese animals have higher blood glucose values than their lean littermates. ${ }^{106}$ These results suggest, since obesity and hyperinsulinemia are manifested well before the presence of hyperglycemia, neither hyperglycemia nor insulin resistance seems to be responsible for the development of the obesity nor of the hyperinsulinemia that occurs in mature $o b / o b$ mice. ${ }^{13}$ However, based on the manifestation of features, the development of obese hyperglycemic syndrome in $o b / o b$ mice can be differentiated into three distinct phases. The first phase is the dynamic phase. After an initial asymptomatic period the dynamic phase is characterized by rapid weight gain, increasing insulin secretion and decreasing glucose tolerance with fasting hyperglycemia. ${ }^{12,25,107}$ The next phase is the transitional phase, which is characterized by shifting of glucose pattern, ie, extremely poor glucose tolerance and extremely high serum insulin level is followed by improving glucose tolerance and decreasing insulin levels. Body weight gradually reaches to its maximum value. In the final static phase, blood glucose and serum insulin levels return to near normal values and body weight slowly decreases. 
Molecular basis of the obese hyperglycemic syndrome

Ingalls et $\mathrm{al}^{2}$ first described the obese hyperglycemic syndrome in 1950 as a single gene mutation in the C57BL/6J mouse strain. Previous studies with $o b / o b$ mice have demonstrated that several experimental techniques reduce the severity of the behavioral and metabolic abnormalities displayed by these mice. For example, treatment with $\beta$-cytotoxic agents, or the implantation of pancreatic islets from lean littermates reduces hyperinsulinemia, hyperglycemia and increased body weight. ${ }^{108-110}$ Adrenalectomies, hypophysectomy, alterations of diet and food restriction are also effective in normalizing some aspects of the obesehyperglycemic syndrome. ${ }^{111-114}$ However, they are not enough to conclude which metabolic disturbance is directly related to the genetic lesion. In an elegant experiment, Coleman ${ }^{5}$ showed that parabiosis of obese mouse $(o b / o b)$ with a normal one suppressed weight gain in the obese mouse, whereas parabiosis to diabetes mouse $(d b / d b)$ caused profound weight lost and death of the obese one. Taken together, these results suggest that the $o b$ gene was necessary for the production of a humoral satiety factor that regulates energy balance and due to the mutation, obese mouse does not produce sufficient satiety factor to turn off its eating drive..$^{5,115}$ This long search for the precise nature of the defect come to an end in 1994, when Zhang et al, ${ }^{10}$ cloned the $o b$ gene and confirmed Coleman's hypothesis.

The $o b$ gene was isolated by positional cloning anc found to encode a highly conserved 167 -amino acic secreted protein that was unique in the GenBank database. ${ }^{10,115}$ Mouse and human $o b$ genes have beer localized to chromosome 6 and 7q31.3, respectively and the product of the $o b$ gene was named Leptin from the Greek leptos, meaning thin. Leptin is synthesizec and secreted primarily, but not exclusively, by whit $\epsilon$ adipose tissue and circulates as $16-\mathrm{kDa}$ protein. Ir C57BL/6J ob/ob mice, a Cys-to-Thr substitution results in a stop codon at position 105 instead of arginine anc produces a truncated protein that is apparently degradec in the adipocyte. ${ }^{115,116}$ Thus, the $o b / o b$ mice are lacking of circulating leptin; and experimental studies showec that leptin replacement corrects almost all of the abnormalities in obese hyperglycemic syndrome. ${ }^{11,60,83,117-121}$ Exogenous administration of leptin inhibits food intake, reduces body weight, stimulates energy expenditure and decreases hyperglycemia and hyperinsulinemia in obese mice (Fig 2). Leptin treated $o b$ mice exhibit normalization of hypoactivity, hypothermia, lower oxygen consumption and re-establishment of fertility. When $o b / o b$ mice are provided with transgene that allows weak expression of a human leptin gene in adipose tissues, hyperinsulinemia and hyperglycemia is prevented or markedly reduced but their obesity and insulin resistance are only partially reduced. ${ }^{122}$ High levels of resistin in obese mice may explain the partial reduction of insulin resistance in leptin-treated $o b / o b$ mice. ${ }^{123}$

Much of the initial research concentrated on the concept that leptin is a satiety factor which inhibits feeding and stimulates energy expenditure by acting on the neural pathways that regulates these actions. ${ }^{122}$ However, with the advent of pleiotropic effects of leptin on many cell types, it seems that the abnormalities in the $o b / o b$ mice are clearly inherited as a consequence of the lack of leptin action which includes modulation of hypothalamic-pituitaryendocrine organ axes (adrenal, thyroid, pancreatic islets, gonadal, growth hormone) as well as control of thermoregulation and of feeding. Other important areas in which leptin has been implicated are hematopoiesis, angiogenesis, and immune response. The consequences of leptin deficiency in $o b / o b$ mice that led to the development of obese hyperglycemic syndrome are summarized in the figure 3 .

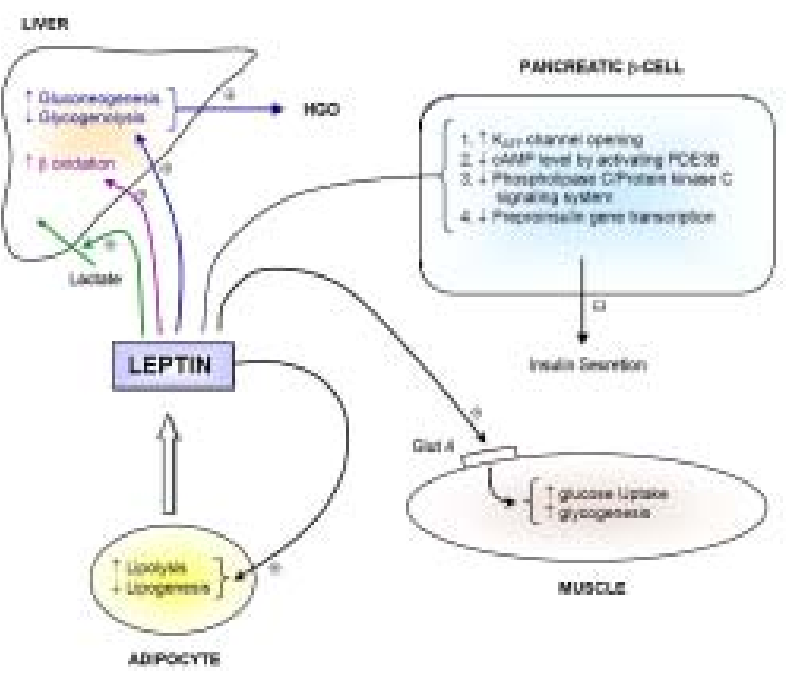

Fig-2. Physiological role of leptin in glucose homesotasis. Leptin stimulates the rate of hepatic glucose output (HGO), inhibits insulin secretion, increases glucose uptake and glycogenesis in muscle. It stimulates lipolysis and decreases lipogenesis in adipoytes. 


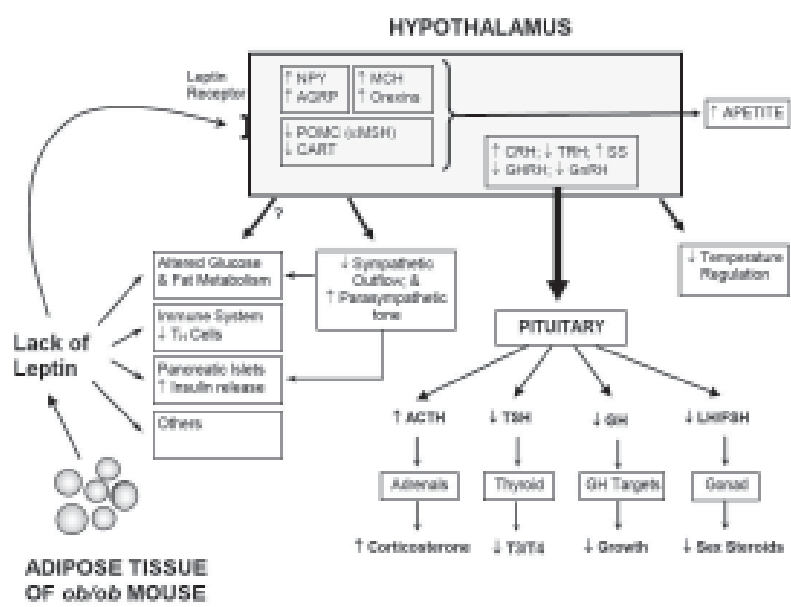

Fig-3. Development of the features in obese hyperglycemic syndrome due to lack of circulating leptin. NPY, AGRP, $P O M C$ and CART neurons are directly responsive to leptin. NPY and AGRP stimulate feeding (orexigenic), whereas ámelanocyte stimulating hormone and CART inhibit feeding (anorexigenic). These neurons also project to the lateral hypothalamus and regulate the expression of melaninconcentrating hormone $(\mathrm{MCH})$ and possibly orexins (hypocretin). Leptin inhibits the expression and secretion of NPY via Y1 receptor. NPY = Neuropeptide $Y ; A G R P$ = agouti-related peptide; $M C H=$ melanin-concentrating hormone; $P O M C=$ proopio-melanocortin; áMSH = ámelanocyte stimulating hormone (a product of POMC); $C A R T=$ cocaine - and amphetamine-regulated transcript; $C R H=$ corticotropin-releasing hormone; $T R H=$ thyrotropin-releasing hormone; SS = somatostatin; GHRH = growth hormone-releasing hormone; GnRH = gonadotropin-releasing hormone; $A C T H=$ Adrenocorticotrpin hormone; TSH $=$ Thyroid-stimulating hormone; $G H=$ Growth hormone; $L H=$ Luteinizing hormone; FSH = Follicle-stimulating hormone; $T 3=$ Tri iodothyronine; $T 4=$ Thyroxine; $T_{H}=$ Helper $T$ cells.

\section{Sequences in development of $o b / o b$ syndrome}

Coleman ${ }^{5}$ speculated that in $o b / o b$ mice hyperphagia persists as a deficiency of satiety factor (later, identified as leptin). Accordingly, the hyperinsulinemia in obese mice would be a result of an unregulated lateral hypothalamus providing overstimulation to the pancreas rather than resulting from hyperphagia. Then hyperphagia and/or hyperinsulinemia would lead to obesity and $\beta$-cell hyperactivity causing compensatory hypertrophy and hyperplasia of the $\beta$-cells (Fig 4). In early development, continued hyperphagia causes increased insulin secretion followed by hyperphagia, which in turn causes further secretion of insulin. The target organs for insulin become maximally stimulated and insulin resistance intervenes, probably to protect the animal against what should be the hypoglycemic effect of the excess insulin.

\section{Use of $o b / o b$ mice}

The obese mice has been used extensively as an animal model for the study of type 2 diabetes mellitus and for the testing of the effectiveness of therapeutic measures for the prevention and therapy of diabetes. However, vascular, retinal and other complications of diabetes are not seen in this mouse model $(o b / o b)$, whereas most of these complications have been described in the phenotypically similar diabetes $(d b / d b)$ mice. ${ }^{14}$ Another caution, as the metabolic abnormalities are dependent on the interaction between the mutation itself and genetic background, ${ }^{5}$ it is necessary for the interpretation of experimental data to mention the source and genetic background of the obese mouse studied. ${ }^{6}$ For example, islets from $o b / o b$ mice of Swedish colony seem to respond adequately to stimulators and inhibitors of insulin release ${ }^{8,9}$ and have been used in the studies involving insulin release, metabolism and stimulus-secretion coupling mechanism without direct comparison with normal islets. However, Findings from $o b / o b$ mice of one colony may not be applicable to other colonies and it is not rational to make a general statement concerning $o b /$ $o b$ mice of all the different colonies.

\section{Human studies}

In humans, circulating leptin concentrations have been reported to correlate closely with the body mass index (BMI), ${ }^{124,125}$ total amount of body fat ${ }^{126}$ as well as the

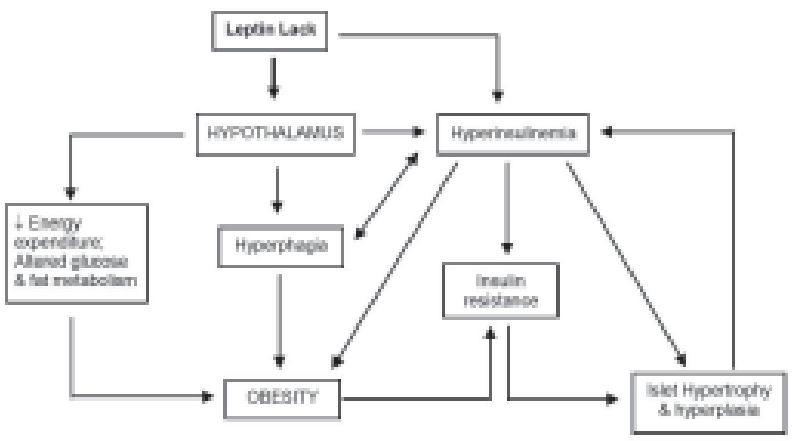

Fig-4. Sequences in the development of ob/ob syndrome due to lack of leptin. 
size of adipose tissue mass. ${ }^{127}$ The normal range for plasma leptin in healthy humans is $3-5 \mathrm{ng} / \mathrm{ml}$ and in obese subjects are in the range of $8-90 \mathrm{ng} / \mathrm{ml} .{ }^{126}$ The increase in serum leptin concentration in obesity involves both the increase in number of adipocytes and induction of $o b$ mRNA. The large adipocytes, which are commonly present in obese subjects due to hypertrophy and hyperplasia of adipose tissue, express more $o b$ mRNA than small adipocytes. ${ }^{128}$ The $o b$ mRNA expression is also upregulated by glucocorticoids. ${ }^{129,130}$ By contrast, stimulation of the sympathetic nervous system or the increase in circulating epinephrine results in inhibition of $o b$ mRNA expression. ${ }^{130}$

The rate of leptin production, in addition to its relation to adiposity, is determined by gender. Plasma leptin concentrations are markedly higher in women than men for any given degree of fat mass. ${ }^{131}$ Similar findings have been observed in Bangladeshi populations where female subjects have plasma leptin values 3 to 4 times higher than their male counterparts irrespective of BMI. ${ }^{25}$ Plasma leptin in women increases during the luteal phase of the menstrual cycle, suggesting that estradiol and progesterone play a significant role in the regulation of leptin secretion by adipose cells. ${ }^{132}$

In human beings, there is a highly organized pattern of leptin secretion over a $24-\mathrm{h}$ period. The circadian pattern is characterized by basal levels between 08:00 and 12:00 hours, rising progressively to peak between 24:00 and 04:00 hours and receding steadily to nadir by 12:00 hours. ${ }^{133}$ However, these changes in leptin plasma concentrations are not acutely altered by food intake or changes in insulin and glucose concentrations in humans. The underlying mechanism is not fully understood, but leptin rhythm seems to be more associated with meal timing than to the circadian clock. ${ }^{134,135}$ It has been speculated that the nocturnal rise in leptin could have an effect in suppressing appetite during the night while sleeping ${ }^{136}$ and since leptin and cortisol show an inverse circadian rhythm, ${ }^{137}$ it has been suggested that a regulatory feedback is present. Glucocorticoids act directly on the adipose tissue and increase leptin synthesis and secretion in humans. ${ }^{138}$ Leptin levels are markedly increased in Cushing's syndrome patients and in other pseudo-Cushing's syndrome states. ${ }^{138}$ However glucocorticoids appears to play a modulatory, but not essential roles in generating leptin diurnal rhythm. Increased leptin secretion glucocorticoids in turn augments coordinated activation of anorexigenic pathways and inhibition of orexigenic pathways mediated by leptin-responsive neurons in the hypothalamus. ${ }^{138,139}$ Furthermore the modulatory role of glucocorticoids could be altered in obesity, but the precise mode of action is still unknown.

As in $o b / o b$ mice, genetic mutations in the leptin gene in humans result in extreme hyperphagia and obesity. ${ }^{140}$ These severely obese, leptin-deficient children respond with normal eating and a selective loss of excess body fat upon being given small amounts of leptin which provide evidences that leptin is an important regulator of energy balance in humans. ${ }^{140,141}$

Human obesity is often associated with severe insulin resistance with high circulating levels of both insulin and leptin. ${ }^{142}$ In this regard, the failure of the elevated leptin levels to restore normal energy and metabolic homeostasis is commonly viewed as evidence for leptin resistance. Resistance is likely caused by a combination of resistance at the receptor and postreceptor levels (level of signaling) as well as a decreased ability of the blood-brain barrier (BBB) to transport circulating leptin into the brain. ${ }^{126}$ Several studies have documented various types of evidence for impaired transport of leptin across the BBB. For example, obese humans have a decreased CSF-to-serum ratio for leptin despite high circulating levels of leptin, and some obese rats that no longer respond to peripherally administered leptin can still respond to leptin given directly into the CNS. ${ }^{126}$ Rising leptin levels associated with progressing obesity are generally regarded as simply a consequence rather than a causative factor in the leptin resistance and obesity. Though serum leptin levels are high in obesity, obese as well as lean subjects with type 2 diabetes display reduced leptin levels. ${ }^{143}$ This lower leptin levels in diabetics have been speculated to contribute in accumulation of cellular lipids that is associated with diabetes. ${ }^{143,144}$

The $o b / o b$ mice are markedly resistant to diet-induced formation of atherosclerosis despite the presence of atherosclerotic risk factors such as diabetes, obesity and hyperlipidemia. ${ }^{23}$ In comparison to mice, in humans selective leptin resistance and the resultant sympathetic activation in response to hyperleptinemia contribute to development of hypertension in patients afflicted with the metabolic syndrome. ${ }^{122}$ Hypoleptinemia has been found to be associated with altered fatty acid composition in type 2 diabetes in Bangladesh. ${ }^{145}$ Serum leptin concentration has also been 
found to be positively associated with insulin secretory capacity and negatively associated with insulin sensitivity in Bangladeshi population. ${ }^{146}$ Insulin secretion from human islets was found to be decreased (77\%) by leptin at a concentration of $1 \mathrm{nmol} / \mathrm{L}$ in the presence of $5.5 \mathrm{mmol} / \mathrm{L}$ glucose. ${ }^{147}$ Similar findings have been observed in rodents ${ }^{147-151}$ and cell lines $^{147,152,153}$ and the mechanism behind decreased insulin secretion can be explained by suppression of insulin mRNA by leptin. ${ }^{147}$ Modulation of insulin secretion by leptin and association of serum leptin concentration with obesity and insulin sensitivity suggest a critical role of this protein in the pathogenesis of type 2 diabetes in humans.

The absolute requirement for leptin in controlling body fat mass and regulating reproduction is firmly shared between mouse and man. ${ }^{154,155}$ Similar to $o b / o b$ mice, leptin helps in regulation of ovarian development and steroidogenesis and serves as either a primary signal initiating puberty or a permissive regulator of sexual maturation. ${ }^{156,157}$ Leptin regulates the growth and development of conceptus, fetal/placental angiogenesis, embryonic hemopoiesis and hormonal biosynthesis within the maternal-fetoplacental unit and could be taken as a marker of fetal mass in humans. ${ }^{157}$ Elevated leptin concentrations in cord blood are associated with macrosomia $^{158}$ and recently, it has been found that leptin levels of amniotic fluid and maternal serum were higher in pregnant women who had fetuses with neural tube defect than in women with healthy fetuses. ${ }^{159}$ Human leptin has been purified and identified in milk and colostrum from nursing mothers and it has been suggested that in the neonatal period it may play a role in the regulation of neonatal food intake and in the intestinal maturation. ${ }^{160,161}$

\section{Clinical implications}

Heterozygous mutations of the $o b$ gene in humans result in a partial deficiency syndrome characterized by increased body adiposity. ${ }^{140}$ The magnitude of leptin deficiency is positively related to the increased sensations of hunger during dieting, ${ }^{162}$ and in another study, reduced appetite has been reported in leptintreated humans. ${ }^{163}$ In addition, it has recently been demonstrated that the normal compensatory decreases of energy expenditure and thyroid axis function in response to consuming an energy-restricted diet in humans can be prevented by low-dose leptin replacement. ${ }^{164}$ Together, these data suggest that decreases of leptin during weight loss could contribute to hunger, a lowered metabolic rate and weight regain. Further studies are needed to determine whether leptin replacement, or the use of strategies to increase endogenous leptin production to prevent the fall of leptin during dieting and weight loss, will help prevent weight regain in weight-reduced subjects. However, it has been well-documented that treatment with recombinant leptin reduces the marked hyperphagia and produces weight loss in leptin-deficient subjects. ${ }^{165}$ Leptin administration also corrects many of the neuroendocrine, reproductive, metabolic and immune system deficits associated with leptin deficiency. ${ }^{166}$

The marked insulin resistance and hyperlipidemia in leptin-deficient rodent models of lipoatrophy is largely reversed by leptin administration. ${ }^{167-169}$ Low-dose leptin treatment has dramatic effects to ameliorate insulin resistance and hyperlipidemia in patients with low leptin levels resulting from congenital or acquired lipodystrophy. ${ }^{170}$ The beneficial metabolic effects were associated with reduced triglyceride deposition in liver and intramyocellular lipid content in skeletal muscle. ${ }^{171,172}$ Leptin also improved pituitary, reproductive, and thyroid axis function in lipoatrophic patients. ${ }^{173}$ Plasma leptin concentrations are also decreased in some patients with lipodystrophy associated with human immunodeficiency virus infection and antiretroviral treatment. ${ }^{174,175}$ It is possible that leptin replacement therapy would be beneficial in managing some of the metabolic abnormalities (hepatic steatosis, hyperlipidemia, and insulin resistance) in the patients with low leptin levels.

\section{Conclusion}

The initial studies in obese hyperglycemic mice, the discovery of leptin and the growing evidences that humans can be genetically determined to become severely obese eventually lead to a more widespread realization that morbid obesity is a disease requiring further scientific research. Systemic effects of leptin on body mass control, reproduction, angiogenesis, cardiovascular function and specific metabolic pathways indicate that leptin operates both directly and indirectly to orchestrate complex physiological processes. These profound effects of leptin on regulating body energy balance make it a prime candidate for drug therapies for humans and animals. A more 
Obesity, diabetes and leptin $\mathbf{8 1}$

complete understanding of the molecular and biochemical pathways regulating the biosynthesis of leptin and its precise mechanisms of action is likely to lead to new approaches for managing obesity, dyslipidemia, insulin resistance and type 2 diabetes.

\section{Acknowledgements}

I gratefully acknowledge Dr MO Faruque, Department of Biochemistry \& Cell Biology, BIRDEM, Dhaka, Bangladesh for kindly reviewing the manuscript. I acknowledge the staff of the Department of Medical Cell Biology and BMC Library, Uppsala University, for their support.

\section{References}

1. Hellman B. Ann N Y Acad Sci 1965; Oct 8;131(1): 541-58.

2. Ingalls AM, Dickie MM, Snell GD. J Hered 1950; 41: 317-8.

3. Friedman JM, Leibel RL, Siegel DS, Walsh J, Bahary N. Genomics 1991; 11(4):1054-62.

4. Herberg L, Coleman DL. Metabolism 1977; 26(1): 59-99.

5. Coleman DL. Diabetologia 1978; 14(3): 141-8.

6. Hansen AK, Dagnaes-Hansen F. An introduction to the use of rodent models in diabetes research: Mollegaard Ltd and Bomholtgaard Ltd. Denmark 1990.

7. Hellman B. Diabetologia 1970; 6(2): 110-20.

8. Hahn HJ, Hellman B, Lernmark Å, Sehlin J, Täljedal IB. J Biol Chem 1974; 249(16): 5275-84.

9. Hellman B, Idahl LÅ, Lernmark Å, Sehlin J, Täljedal IB. Arch Biochem Biophys 1974; 162(2): 448-57.

10. Zhang Y, Proenca R, Maffei M, Barone M, Leopold L, Friedman JM. Nature 1994; 372(6505): 425-32.

11. Halaas JL, Gajiwala KS, Maffei M, Cohen SL, Chait BT, Rabinowitz D, et al. Science 1995; 269(5223): 543-6.

12. Westman S. Diabetologia 1968; 4(3): 141-9.

13. Dubuc PU. Metabolism 1976; 25(12): 1567-74.

14. Coleman DL. Diabetes 1982; 31(Suppl 1 Pt 2):1-6.

15. Ktorza A, Bernard C, Parent V, Penicaud L, Froguel P, Lathrop M, et al. Diabetes Metab 1997; 23 (Suppl 2): $38-46$.

16. Boissonneault GA, Hornshuh MJ, Simons JW, Romsos DR, Leveille GA. Proc Soc Exp Biol Med 1978; 157(3): 402-6.
17. Trayhurn P, James WP. Pflügers Arch 1978; 373(2): 189-93.

18. Bray GA, York DA. Physiol Rev 1979; 59(3): 719-809.

19. Fruhbeck G, Salvador J. Diabetologia 2000; 43(1): 3-12.

20. Seidman I, Horland AA, Teebor GW. Diabetologia 1970; 6(3): 313-6.

21. Shafrir E. Diabetes Metab Rev 1992; 8(3): 179-208.

22. Uysal KT, Scheja L, Wiesbrock SM, Bonner-Weir S, Hotamisligil GS. Endocrinology 2000; 141(9): 3388-96.

23. Nishina PM, Lowe S, Wang J, Paigen B. Metabolism 1994; 43(5): 549-53.

24. Johnson PR, Hirsch J. J Lipid Res 1972; 13(1): 2-11.

25. Herberg L, Major E, Hennigs U, Gruneklee D, Freytag G, Gries FA. Diabetologia 1970; 6(3): 292-9.

26. Garthwaite TL, Martinson DR, Tseng LF, Hagen TC, Menahan LA. Endocrinology 1980; 107(3): 671-6.

27. Leckström A, Lundquist I, Ma Z, Westermark P. Pancreas 1999; 18(3): 266-73.

28. Lane PW, Dickie MM. J Nutr 1958; 64: 549-54.

29. Smith BA, Edwards MS, Ballachey BE, Cramer DA, Sutherland TM. Growth Dev Aging 1991; 55(2): 81-9.

30. Gepts W, Christophe J, Mayer J. Diabetes 1960; 9(1): 63-9.

31. Hellman B, Brolin S, Hellerström C, Hellman K. Acta Endocrinol 1961; 36: 609-16.

32. Starich GH, Zafirova M, Jablenska R, Petkov P, Lardinois CK. Acta Histochem 1991; 90(1): 93-101.

33. Hellman B. Acta Endocrinol 1961; 36: 596-602.

34. Petersson B, Hellman B. Metabolism 1962; March; 11(3): 342-8.

35. Tassava TM, Okuda T, Romsos DR. Am J Physiol 1992; 262(3 Pt 1): E338-E43.

36. Makino H, Matsushima Y, Kanatsuka A, Yamamoto M, Kumagai A, Nishimura M. Endocrinology 1979; 104(1): 243-7.

37. Wrenshall GA, Andrus SB, Mayer J. Endocrinology 1955; 56(March): 335-40.

38. Hellman B, Petersson B. Acta Path Microbiol Scand 1960; 50(3): 291-6.

39. Bjorkman N, Hellerstrom C, Hellman B. Zeitschrift fur Zellforschung 1963; 58: 803-19. 
40. Rooth P, Grankvist K, Taljedal IB. Microvasc Res 1985; 30(2): 176-84.

41. Beloff-Chain A, Newman ME, Mansford KR. Diabetologia 1973; 9(6): 447-52.

42. Gingerich RL, Gersell DJ, Greider MH, Finke EH, Lacy PE. Metabolism 1978; 27(10): 1526-32.

43. Dolais-Kitabgi J, Marchand-Brustel Y, Freychet P. Diabetologia 1979; 17(4): 257-61.

44. Tomita T, Doull V, Kimmel JR, Pollock HG. Diabetologia 1984; 27(4): 454-9.

45. Tomita T, Doull V, Pollock HG, Krizsan D. Pancreas 1992; 7(3):367-75.

46. Petersson B, Lundqvist G, Andersson A. Experientia 1979; 35(1): 127-8.

47. Chen NG, Tassava TM, Romsos DR. J Nutr 1993; 123(9): 1567-74.

48. Lernmark Å, Hellman B. Life Sci 1969; 8(2): 53-9.

49. Newman ME. Horm Metab Res 1977; 9(5): 358-61.

50. Khan A, Chandramouli V, Ostenson CG, Berggren PO, Low H, Landau BR, et al. Endocrinology 1990; 126(5): 2413-6.

51. Khan A, Efendic S. Am J Physiol 1995; 269(4 Pt 1): E623-6.

52. Rosario LM, Atwater I, Rojas E. Q J Exp Physiol 1985; 70(1): 137-50.

53. Scott AM, Dawson CM, Goncalves AA. J Endocrinol 1985; 107(2): 265-73.

54. Fournier LA, Heick HM, Begin-Heick N. Biochem Cell Biol 1990; 68(1): 243-8.

55. Fournier L, Begin-Heick N, Whitfield JF, Schwartz JL. J Membr Biol 1992; 129(3): 267-76.

56. Black MA, Fournier LA, Heick HM, Begin-Heick N. Biochem J 1988; 249(2): 401-7.

57. Wroblewski R, Palsgard E, Juntti-Berggren L, Berggren PO, Roomans GM. Pancreas 1998; 16(2): 134-40.

58. Black M, Heick HM, Begin-Heick N. Biochem J 1986; 238(3): 863-9.

59. Fournier L, Whitfield JF, Xiang H, Schwartz JL, Begin-Heick N. Am J Physiol 1993; 264(6 Pt 1): C1458-C65.

60. Ahmed M, Grapengiesser E. Endocrine 2001; 15(1): 73-8.

61. Atkins T, Matty AJ. J Endocrinol 1971; 51: 61-78.

62. Black MA, Heick HM, Begin-Heick N. Am J Physiol 1988; 255(6 Pt 1):E833-E8.

63. Lavine RL, Voyles N, Perrino PV, Recant L. Endocrinology 1975; 97(3): 615-20.
64. Chen NG, Romsos DR. Endocrinology 1995; 136(2): 505-11.

65. Zawalich WS, Zawalich KC. Biochem Biophys Res Commun 1996; 223(3): 618-23.

66. Chen NG, Romsos DR. Am J Physiol 1997; 272(2 Pt 1):E304-E11.

67. Chan CB. Can J Physiol Pharmacol 1995; 73(10): 1414-24.

68. Lindstrom P, Lundquist I. Role of monoamines and monoaminergic mechanisms in insulin release. In: Flatt PR, Lenzen S, eds. Insulin secretion and pancreatic B-cell research: Smith-Gordon 1994; 369-74.

69. Panagiotidis G, Lindstrom P, Stenstrom A, Lundquist I. Metabolism 1993; 42(11): 1398-404.

70. Carstensen H, Hellman B, Larsson S. Acta Soc Med Upsal 1961; 3-4: 139-51.

71. Nathorst-Windahl G, Hellman B. Med Exp 1964; 10: $67-71$

72. Bergstrand A, Nathorst-Windahl G, Hellman B. Acta Pathol Microbiol Scand 1968; 74(2): 161-8.

73. Hellman B, Jacobsson L, Taljedal IB. Acta Endocrinol 1963; 44: 20-6.

74. Batt RA, Harrison GA. J Hered 1963; 54: 135-8.

75. Swerdloff RS, Batt RA, Bray GA. Endocrinology 1976; 98(6): 1359-64.

76. Westman S. Diabetologia 1970; 6(3): 279-83.

77. Fournier L, Whitfield JF, Schwartz JL, Bégin-Heick N. J Biol Chem 1994; 269(2): 1120-4.

78. Mahler RJ, Dubuc PU, Mobley PW, Ensinck JW. Horm Metab Res 1976; 8(1): 79-80.

79. Dunbar JC, Walsh MF. Horm Metab Res 1980; 12(1): 39-40.

80. Flatt PR, Bailey CJ, Buchanan KD. Biochem Soc Trans $1980 ; 8(1): 57-8$.

81. Flatt PR, Buchanan KD, Bailey CJ. Biochem Soc Trans $1980 ; 8$ 8(1): 58-9.

82. Leigh FS, Kaufman LN, Young JB. Int J Obes Relat Metab Disord 1992; 16(8): 597-604.

83. Chehab FF, Lim ME, Lu R. Nat Genet 1996; 12(3): 318-20.

84. van der Kroon PH, Boldewijn H, Langeveld-Soeter N. Int J Obes 1982; 6(1): 83-90.

85. Oh SS, Kaplan ML. Proc Soc Exp Biol Med 1994; 207(3): 260-7.

86. Dubuc PU. Horm Metab Res 1989; 21(10): 546-9.

87. Burcelin R, Kamohara S, Li J, Tannenbaum GS, Charron MJ, Friedman JM. Diabetes 1999; 48(6): 1264-9. 
Obesity, diabetes and leptin $\mathbf{8 3}$

88. Gambert SR, Garthwaite TL. Horm Metab Res 1981; 13(10): 588-9.

89. Hillgartner FB, Romsos DR. Am J Physiol 1985; 249(2 Pt 1): E209-E18.

90. Kaplan MM, Young JB, Shaw EA. Endocrinology 1985; 117(5): 1858-63.

91. Mobley PW, Dubuc PU. Horm Metab Res 1979; 11(1): $37-9$.

92. Ozata M, Ozdemir IC, Licinio J. J Clin Endocrinol Metab 1999; 84(10): 3686-95.

93. Dubuc PU. Endocr Regul 1991; 25(3): 171-5.

94. Kates AL, Himms-Hagen J. Biochem Biophys Res Commun 1985; 130(1): 188-93.

95. Hillgartner FB, Romsos DR. Am J Physiol 1987; 252(3 Pt 1): E414-E9.

96. Hillgartner FB, Romsos DR. AmJ Physiol 1988; 255(1 Pt 1): E54-E8.

97. Lin MH, Vander Tuig JG, Romsos DR, Akera T, Leveille GA. Am J Physiol 1979; 237(3): E265-E72.

98. Knehans AW, Romsos DR. Am J Physiol 1982; 242(4): E253-E61.

99. Trayhurn P. Prog Clin Biol Res 1988; 265: 69-85.

100. Fraser DR, Trayhurn P. Biochem J 1983; 214(1): 163-70.

101. Lin MH, Romsos DR, Akera T, Leveille GA. Metabolism 1981; 30(5): 431-8.

102. Goodson WH, III, Hunt TK. Diabetes 1986; 35(4): 491-5.

103. Ring BD, Scully S, Davis CR, Baker MB, Cullen MJ, Pelleymounter MA, et al. Endocrinology 2000; 141(1): 446-9.

104. Genuth SM, Przybylski RJ, Rosenberg DM. Endocrinology 1971; 88(5): 1230-8.

105. Joosten HF, van der Kroon PH. Metabolism 1974; 23(5): 425-36.

106. Edvell A, Lindstrom P. Metabolism 1995; 44(7): 906-13.

107. Hunt CE, Lindsey JR, Walkley SU. Fed Proc 1976; 35(5): 1206-17.

108. Mahler RJ, Szabo O. Am J Physiol 1971; 221(4): 980-3.

109. Solomon J, Bulkley RJ, Mayer J. Diabetologia 1974; 10(6): 709-15.

110. Strautz RL. Diabetologia 1970; 6(3): 306-12.

111. Hellerstrom C, Westman S, Herbai G, Petersson B, Westman J, Borglund E, et al. Diabetologia 1970; 6(3): 284-91.

112. Lemonnier D, Winand J, Furnelle J, Christophe J. Diabetologia 1971; 7(5): 328-33.
113. Naeser P. Diabetologia 1973; 9(5): 376-9.

114. Cuendet GS, Loten EG, Cameron DP, Renold AE, Marliss EB. Am J Physiol 1975; 228(1): 276-83.

115. Friedman JM, Halaas JL. Nature 1998; 395(6704): 763-70.

116. Ahima RS, Flier JS. Annu Rev Physiol 2000; 62: 413-37.

117. Campfield LA, Smith FJ, Guisez Y, Devos R, Burn P. Science 1995; 269(5223): 546-9.

118. Pelleymounter MA, Cullen MJ, Baker MB, Hecht R, Winters D, Boone T, et al. Science 1995; 269(5223): 540-3.

119. Weigle DS, Bukowski TR, Foster DC, Holderman S, Kramer JM, Lasser G, et al. J Clin Invest 1995; 96(4): 2065-70.

120. Mounzih K, Lu R, Chehab FF. Endocrinology 1997; 138(3): 1190-3.

121. Lord GM, Matarese G, Howard JK, Baker RJ, Bloom SR, Lechler RI. Nature 1998; 394(6696): 897-901.

122. Himms-Hagen J. Crit Rev Clin Lab Sci 1999; 36(6): 575-655

123. Steppan CM, Bailey ST, Bhat S, Brown EJ, Banerjee RR, Wright CM, et al. Nature 2001; 409(6818): 307-12.

124. Takahashi M, Funahashi T, Shimomura I, Miyaoka K, Matsuzawa Y. Horm Metab Res 1996; 28(12): 751-2.

125. Saha AR, Roy MN, Biswas KB, Paul DT, Aktar S, Ali L. JIMJ 2007; 3(1): 123-8.

126. Arora S. Diabetes Obes Metab 2008.

127. Jequier E. Ann N Y Acad Sci 2002; 967: 379-88.

128. Hamilton BS, Paglia D, Kwan AY, Deitel M. Nat Med 1995; 1(9): 953-6.

129. Halleux CM, Servais I, Reul BA, Detry R, Brichard SM. J Clin Endocrinol Metab 1998; 83(3): 902-10.

130. Slieker LJ, Sloop KW, Surface PL, Kriauciunas A, LaQuier F, Manetta J, et al. J Biol Chem 1996; 271(10): 5301-4.

131. Janeckova R. Physiol Res 2001; 50(5): 443-59.

132. Cella F, Giordano G, Cordera R. Eur J Endocrinol 2000; 142(2): 174-8.

133. Sinha MK, Sturis J, Ohannesian J, Magosin S, Stephens T, Heiman ML, et al. Biochem Biophys Res Commun 1996; 228(3): 733-8.

134. Schoeller DA, Cella LK, Sinha MK, Caro JF. J Clin Invest 1997; 100(7): 1882-7.

135. Elimam A, Marcus C. Eur J Endocrinol 2002; 147(2): 181-8. 
136. Sinha MK, Ohannesian JP, Heiman ML, Kriauciunas A, Stephens TW, Magosin S, et al. J Clin Invest 1996; 97(5): 1344-7.

137. Licinio J, Mantzoros C, Negrao AB, Cizza G, Wong ML, Bongiorno PB, et al. Nat Med 1997; 3(5): 575-9.

138. Leal-Cerro A, Soto A, Martinez MA, Dieguez C, Casanueva FF. Pituitary 2001; 4(1-2): 111-6.

139. Dagogo-Jack S, Tykodi G, Umamaheswaran I. J Clin Endocrinol Metab 2005; 90(9): 5333-5.

140. Montague CT, Farooqi IS, Whitehead JP, Soos MA, Rau H, Wareham NJ, et al. Nature 1997; 387(6636): 903-8.

141. O'Rahilly S. Nutr Rev 2002; 60(10 Pt 2): S30-4; discussion S68-84, 5-7.

142. Zimmet P, Boyko EJ, Collier GR, de Courten M. Ann N Y Acad Sci 1999; 892: 25-44.

143. Sayeed MA, Azad Khan AK, Mahtab H, Ahsan KA, Banu A, Khanam PA, et al. Diabetes Care 2003; 26(2): 547.

144. Unger RH, Zhou YT, Orci L. Proc Natl Acad Sci U S A 1999; 96(5): 2327-32.

145. Aktar S. Role of leptin in the pathogenesis of Type 2 diabetes mellitus. Dhaka: University of Dhaka; 2007.

146. Karim SKA, Faruque MO, Biswas KB, Nahar Q, Mahtab H, Ali L. Diab Endocr J 2006; 34(1): 9-15.

147. Kulkarni RN, Wang ZL, Wang RM, Hurley JD, Smith DM, Ghatei MA, et al. J Clin Invest 1997; 100(11): 2729-36.

148. Fehmann HC, Peiser C, Bode HP, Stamm M, Staats P, Hedetoft C, et al. Peptides 1997; 18(8): 1267-73.

149. Kieffer TJ, Heller RS, Leech CA, Holz GG, Habener JF. Diabetes 1997; 46(6): 1087-93.

150. Ookuma M, Ookuma K, York DA. Diabetes 1998; 47(2): 219-23.

151. Poitout V, Rouault C, Guerre-Millo M, Briaud I, Reach G. Endocrinology 1998; 139(3): 822-6.

152. Ahrén B, Havel PJ. Am J Physiol 1999; 277(4 Pt 2): R959-R66.

153. Zhao AZ, Bornfeldt KE, Beavo JA. J Clin Invest 1998; 102(5): 869-73.

154. Mantzoros CS. Ann NY Acad Sci 2000; 900: 174-83.

155. Moschos S, Chan JL, Mantzoros CS. Fertil Steril 2002; 77(3): 433-44.

156. Caprio M, Fabbrini E, Isidori AM, Aversa A, Fabbri A. Trends Endocrinol Metab 2001; 12(2): 65-72.
157. Henson MC, Castracane VD. Biol Reprod 2000; 63(5): 1219-28.

158. Lepercq J, Lahlou N, Timsit J, Girard J, Mouzon SH. Am J Obstet Gynecol 1999; 181(3): 621-5.

159. Basbug M, Serin IS, Ozcelik B, Kula M, Basbug EM, Tutus A. Obstet Gynecol 2003; 101(3): 523-8.

160. Casanueva FF, Dieguez C. Front Neuroendocrinol 1999; 20(4): 317-63.

161. Baldelli R, Dieguez C, Casanueva FF. Ann Med 2002; 34(1): 5-18.

162. Keim NL, Stern JS, Havel PJ. Am J Clin Nutr 1998; 68(4): 794-801.

163. Westerterp-Plantenga MS, Saris WH, Hukshorn CJ, Campfield LA. Am J Clin Nutr 2001; 74(4): 426-34.

164. Rosenbaum M, Murphy EM, Heymsfield SB, Matthews DE, Leibel RL. J Clin Endocrinol Metab 2002; 87(5): 2391-4.

165. Farooqi IS, Jebb SA, Langmack G, Lawrence E, Cheetham CH, Prentice AM, et al. N Engl J Med 1999; 341(12): 879-84.

166. Farooqi IS, Matarese G, Lord GM, Keogh JM, Lawrence E, Agwu C, et al. J Clin Invest 2002; 110(8): 1093-103.

167. Berg JP. Eur J Endocrinol 2000; 142(2): 114-6.

168. Ebihara K, Ogawa Y, Masuzaki H, Shintani M, Miyanaga F, Aizawa-Abe M, et al. Diabetes 2001; 50(6): 1440-8.

169. Colombo C, Cutson JJ, Yamauchi T, Vinson C, Kadowaki T, Gavrilova O, et al. Diabetes 2002; 51(9): 2727-33.

170. Oral EA, Simha V, Ruiz E, Andewelt A, Premkumar A, Snell P, et al. N Engl J Med 2002; 346(8): 570-8.

171. Petersen KF, Oral EA, Dufour S, Befroy D, Ariyan $\mathrm{C}, \mathrm{Yu} \mathrm{C}$, et al. J Clin Invest 2002; 109(10): 1345-50.

172. Simha V, Szczepaniak LS, Wagner AJ, DePaoli AM, Garg A. Diabetes Care 2003; 26(1): 30-5.

173. Oral EA, Ruiz E, Andewelt A, Sebring N, Wagner AJ, Depaoli AM, et al. J Clin Endocrinol Metab 2002; 87(7): 3110-7.

174. Estrada V, Serrano-Rios M, Martinez Larrad MT, Villar NG, Gonzalez Lopez A, Tellez MJ, et al. J Acquir Immune Defic Syndr 2002; 29(1): 32-40.

175. Gan SK, Samaras K, Thompson CH, Kraegen EW, Carr A, Cooper DA, et al. Diabetes 2002; 51(11): 3163-9. 